\title{
Public Transport Pricing in Nigeria
}

\author{
Wojuade Christopher Adesola \\ Department of Transport Management, \\ Ladoke Akintola University of Technology, Ogbomoso, Nigeria
}

\begin{abstract}
Public transport is an important social service that satisfies the travel needs of citizens. Hence, the need to regulate transit operations especially fare so as to make it affordable to the riders. This study examines the regulation and pricing of public transport operations in Lagos, Nigeria. The required data was sourced from executives of National Union of Road Transport Workers unions and 200 willing passengers at Oshodi and Obalende parks. Findings show that there is no government agency regulating fare in the study area although the power is vested on Lagos Metropolitan Area Transport Authority. The fixing and regulation of fare is the prerogative of the private transit operators. This encouraged arbitrary hiking of fare without any justifiable reasons. The result of transit pricing indicates that the operators' charges fare to realise enough revenue to cover all costs and make profit. The method employed though not formal share some similarities with second best pricing in which all costs are met by setting price equal to average cost. They employed zonal fare structure graduated by distance to determine the fare paid by passengers. The factors that determine the fare charge are types of vehicle, quality of service, operating costs and road conditions. The passengers' perceived that transport fare is high and does not correspond to services rendered by transit operators. Surprisingly, some passengers spent more than half of their monthly income on fare. The study concludes that transit pricing is not regulated in Lagos and probably in some other parts of the country, which has socio-economic implications on the transit riders.
\end{abstract}

Keywords: Public transport, transit pricing, public/private transit operator, fare

\section{INTRODUCTION}

Transport service is important in providing access to spatially distributed activities such as employment, education and shopping in cities (Deb and Filippini 2011). Public transport plays a major role in the provision of this service. This is due to the fact that public transport is widely regarded as a social service which is used to satisfy the transport needs of people especially the less privileged in the society who cannot afford personal car (Gkritza et al, 2011 and Akin, 2006). It has ability to convey more passengers, cheaper, reduces traffic congestion and greenhouse gas emissions and creates a better urban environment.

Fare is a vital component of public transport service. It is the amount paid by passengers to transit operators for the transport services rendered. Fare can increase or reduce patronage of transit services. The revenue realised from transit fare determines the ability of public transit operators to remain in business. The main objective of transit operators is to increase revenue in response to operating costs. However, public transport being a social service has to be affordable to passengers it is provided for. Hence, there is need for adequate pricing and regulation of transit operations. This is to avert the effect of high fare on low-income individuals and households who heavily rely on public transit as their only means of transportation (Anas and Lindsey, 2011). 
Pricing of public monopoly like bus service is a serious task. The determination of appropriate pricing scheme for bus services is a difficult task for regulatory agencies (Garcia and Reynaud, 2004). Public transport is viewed as a natural monopoly producing social service financed by government without any consideration for economic performance. The pricing does not generate adequate revenue to recover costs and sustain the services. This pricing is threatened by the dwindling financial fortune of some government and competing uses for limited fund. The paradigm has changed towards finding an efficient pricing that has significant economic gain and socially beneficial to the passengers. Public transport is now viewed as a service that requires economic efficiency. The optimal pricing of public transport services that ensure economic efficiency and cost recovery is critical to a sustainable public transport system (Deb and Filippini, 2011).

Public transportation in Nigeria is a fait accompli because majority of the people depend on it for their travel needs (Okoko, 2006). Most of the citizens are low-income earners who cannot afford personal cars. The public transport system in the country is mainly road based. Although a social service, public transport operation is dominated by private transit operators (World Bank, 1990). The private operators do not have any formal training in bus operation (Ojekunle, 2014). The para-transit modes such as minibuses, vans and shared taxis used by the private operators have low occupancy capacity, higher operating costs (compared to bus) and increase traffic volume on highways causing congestion, time loss, accident and other related externalities that increase fare (Fadare and Wojuade, 2007). The majority of government (public) transit companies were run at loss and had folded up due to mismanagement, political interference, lack of trained personnel and commitment by employees and poor maintenance culture (Ogunbodede, 2008; Ikporukpo, 1998 and World Bank, 1990).

There is evidence that bus services are regulated in developed countries (Preston, 2014; Baker and White, 2010; Savage and Schupp, 1997; Button, 1986; and White, 1981). There is scanty information on transit pricing in Nigeria, for example, Ojekunle (2014) focus on northern part of the country. The need to understand how the activities of the private transit operators are regulated becomes necessary. This study explores the agency regulating transit fare; pricing of fare; factors determining fare and effect of fare on passengers in the southern part of the country using Lagos as a case study.

\section{LITERATURE}

Fare is a major factor determining the demand for public transport (Ndikom, 2006). Also, it is the main source of revenue for transit operators (Paulley et. al, 2006). The revenue for public transport operators comprise of fare-box collection and subsidy from government (Deb and Filippini, 2011). Fare is usually priced based on a single trip or journey. Okoko (2006) identified three different types of fare. Zonal fare is uniform within a zone but changes as one move into another zone. Distance plays a major role in determining the fare paid. This fare generates more revenue but it is susceptible to fraud. Flat fare is uniform regardless of the distance travelled. It is simple to collect and amount collected can easily be determined (Nuworsoo et al, 2011). Flat fare generates low revenue which may necessitates subsidy from the government. It is sometimes used to increase ridership of public transit especially in congested city centres. Season-based fare normally enjoys discount and is valid for a period of time e.g week, month or year. There is no restriction on the number of trips that can be made within the validity period. This fare increases the revenue base of the operator because tickets are sold in advance reducing daily fare collection and fraudulent practices. However, only few passengers can afford to buy season ticket due to high cost. 
Public transport is a natural monopoly that needed to be regulated to ensure that both the consumers and producers benefit economically. Fare regulation is the process that determines the amount of profit transit operator expects to realise. There is need for price efficiency to encourage passengers to patronise transit services. Adeniji (1987) identified three regulatory options for setting fare. The first option, government fare setting allows government at local or city levels to determine the best fare for transit operators and the public. Passengers know the exact fare payable to the transit operators, thus eliminating overcharging and exploitation. The main challenge is that transit operators are at the mercy of government to increase fare when the operating costs increased. Second, transit operators' fare setting that gives opportunity to charge fare up to a stipulated maximum cap for most of their business (Ndikom, 2006). This regulation encourages minimal competition between government and the operators. Third, special industry fare setting gives transit operators the role of regulating fare. However, government monitors the frequency operators change the fare annually to ensure they did not violate the right to set fare. Fare can quickly and easily be adjusted when needed unlike in government fare setting.

The prime function of the regulatory authorities is to determine the appropriate pricing scheme for the services provided by public utilities. The pricing policies are designed to achieve economic efficiency. The main objective of transit operators is to generate revenue that covers costs (Garcia and Reynaud, 2004). Hence, this calls for designing efficient pricing regimes for the provision of transit services that strike a balance between revenue adequacy and price efficiency. This will ensure revenue adequacy for the transport operators to remain in business and price efficiency for the passengers. The first best and second best pricing is discussed in the following section.

\section{First best pricing}

The use of marginal cost pricing would maximize social welfare in bus transit services (Rothengatter, 2003). Marginal cost pricing is the difference between willingness of consumers to pay for the services and the cost of producing them (Gomex-Ibanez, 1999). Marginal cost pricing assumes that there are no externalities in production and consumption. In reality, these externalities existed and ought to be accounted for in cost to maximize the net social benefit. For example, bus fare should comprise of both the actual cost of use and external costs of emissions and congestion. This pricing leads to deficit for a firm operating with economies of scale if all units of output are sold at a uniform price (Braeutigam, 1989). This will make the firm to have revenue inadequacy and external financial support becomes necessary to cover the deficit. Marginal cost pricing can achieve first best pricing only if subsidy is provided to the transit firm either through tax or subsidy from government, which may be quite costly. On the other hand, Rothengatter (2003) reiterates that marginal cost pricing will give the first best outcome only if: all costs (direct, indirect and external) are accounted for in marginal pricing; there is perfect competition in market; perfect division of investment for growth of infrastructure in service delivery and area coverage; adequate information is provided; and transport technology is convex to allow full cost recovery.

But if the regulator has no powers for subsidy or taxation, they are faced with need to find a pricing policy that avoid deficit for the transit firm. Peak loading pricing can achieve first best pricing. It is a form of scheme that discriminate price across time periods. This can be expressed as:

$$
Y_{\mathrm{t}}=f\left(x_{\mathrm{t}}, k\right)
$$

The three essential features of peak loading pricing are: 
i. $\quad$ Firm must provide service over a period of time with different demand schedules;

ii. Production must take place at a single plant over a period of time; and

iii. The output must be nonstorable to avoid firm producing more than demanded in off peak to serve the higher demand in peak.

The principle of peak loading pricing is based on the fact that plant is shared by users of all time periods and the cost should be borne by all users. For example, peak loading pricing principle can be divided into daytime peak period and evening/night off peak period in transit business. The off peak users would pay only for the variable costs of production whereas peak period users would pay variable costs of production and fixed costs. Thus, it leads to first best and allow the firm to break even. Therefore, first best and revenue adequacy can be achieved simultaneously with peak loading pricing.

\section{Second best pricing}

In a case that firm is unable to break even when uniform price is set equal to marginal cost for each of the services offered. Then, the price to be charged will deviate from marginal costs so as to maximize economic efficiency and avoid deficit. Pricing at average cost for a single product firm would achieve second best. This pricing regime ensures that all costs are met by setting price equal to the average cost, also known as revenue-recovery principle. White (1981) express average cost pricing mathematically as:

$$
P(y)=\frac{C(y)}{y}
$$

Where $C(y)$ is the total cost of providing $y$.

At any price less than average cost, the firm will incur deficit which violates the breakeven constraint and at a cost greater than average cost, the firm will remain profitable but the size of the dead weight loss is larger than when prices equal average cost. The second best price achieved maximum net economic benefits and minimizing the deadweight loss on the profit of the firm. The main challenge is that dead weight loss result in loss of economic efficiency due to non-reflection of marginal costs and demand (Deb and Filippini, 2011). In the transport sector, average cost is calculated by dividing the total cost by the number of passenger per kilometre of journey. The average price obtained is a flat fare paid by passengers per trip. The fare charged by transit operators covered all the costs of operation.

The theories of regulating natural monopolies such as public transport companies by regulatory agencies will be applied to the situation in Nigeria to ascertain how transit operations is regulated and priced. The findings will be useful in drawing conclusions on the effectiveness of the pricing and necessary policy actions to help improve upon it.

\section{STUDY AREA AND METHODOLOGY}

Lagos is situated in the Southwestern part of Nigeria. It has the largest urban conurbation in the country and one of the fastest growing cities all over the world. The population of Lagos is $9,013,534$ (NPC, 2007) but the figure has been argued to be about 18.5 million. Lagos has a total land area of $3,577 \mathrm{~km}^{2}$ with a population density of 2,500 persons per $\mathrm{km}^{2}$. The historical, administrative and colonial influence of Lagos helped to fuel its growth. Today, Lagos as the major commercial nerve centre in the country has the largest concentration of manufacturing and service industries and transport infrastructures such as highways, seaports and airports. It provides access to eastern, western and northern part of the country. 
The Ministry of Transport and Works, Lagos Metropolitan Area Transport Authority (LAMATA) and Lagos State Traffic Management Authority (LASTMA) manage transport operations in Lagos. They are responsible for construction and maintenance of roads; planning, regulation and co-ordination of public transport modes bus, train and ferry services and traffic management in Lagos. The Road Transport Employers Association of Nigeria (RTEAN) and the National Union of Road Transport Workers (NURTW) provide the road passenger transport in Lagos and the country as a whole. The Road Transport Employers Association of Nigeria owns large buses and dominates inter urban services e.g ABC transport Limited, Chisco Transport Limited and Cross Country Limited. The National Union of Road Transport Workers dominates the urban transport sector using mini buses. This mini bus dominates public transport supply in Lagos. The 6 million daily passenger trips in the city are catered for majorly by 75,00090,000 mini/midi buses and shared taxis. Majority of the drivers do not own the bus but pay daily rental fee (deliver) to the owners (World Bank, 2011). The drivers meet the operating cost while the owner is responsible for the vehicle documents, maintenance and repairs. In addition, some organizations partner with government to provide transport services in Lagos. For example, the Bus Rapid Transit (BRT) and Lagbus are public/private partnership initiatives to provide rapid travel to passengers on dedicated lanes in the city. The passengers make the choice of transport services to travel in based on factors such as affordability of fare, safety and comfort.

The National Union of Road Transport Workers have national, state and local branches where the operations of the union are performed. Two bus parks Oshodi and Obalende parks in Lagos mainland and island respectively were selected for this study. The study employed both interview and survey of questionnaire to obtain necessary information. The interview was conducted on the executives of NURTW unions. A branch each was selected for intra and inter city transport services interview survey at the parks. They were asked questions on the agency that regulates transit pricing, how the fare is set and factors considered in setting the fare. Also, there was administration of questionnaires on 200 passengers at the bus parks, that is, 100 each at Oshodi and Obalende bus parks. The questionnaire was administered on passengers that are willing to provide the required information. The purposive incidental sampling technique was utilised since the total population passengers cannot be predetermined. This sampling technique eliminates bias as it affords every willing passenger the opportunity to be sampled. The questionnaire elicit information on the perception of passengers to fare charged and services rendered by the transit operators. The findings of the survey are discussed in the preceding sections of the paper.

\section{RESULT AND DISCUSSION}

The findings of the survey on transit pricing practice in Lagos, Nigeria is discussed in this section under the following headings: agency regulating transit fare, fare pricing, factors determining fare charged and perception of passengers to transit fare.

\section{The Agency Regulating Transit Fare}

The respondents were asked to indicate the government agency that regulates transport fare. It is surprising they all indicated that no government agency take part in regulation of transit fare. The power to regulate transport operations in Lagos is vested on Lagos State Traffic Management Authority (World Bank, 2011). This is enshrined in its revised law in 2006 which state its function inter alia to "plan, regulate and co-ordinate the supply of adequate and effective public transport in all travel modes and support infrastructure within metropolitan Lagos". Apart from this, federal laws empower Motor Vehicle Administration set up under National Road Traffic Regulations (1997) and Federal Road Safety Commission Act to set maximum and minimum fare that local bus operators can charge (World Bank, 2011). 
However, Lagos State Traffic Management Authority (LAMATA) did not regulate or control the fare charge by private transit operators' in Lagos. The state agency failed to discharge its duties as stipulated in the law that established her. The lack of regulation of public transport operations is responsible for its chaotic and unorganized nature in the country (Ojekunle, 2014).

The fixing and regulation of fare for pubic transport operations in Lagos and in some parts of the country has become the prerogative of the private transit operators and their unions. This is contrary to the practise in developed countries where government authorities regulate bus services. For example, competition commission regulates bus services in the United Kingdom. This act is against the purpose of public transportation which is a social service provided mainly for the poor who cannot afford personal car. The fixing of fare by transit operators without any control by government discourages competition and exposes the passengers to exploitation by the operators.

The inability of government to exercise control over the fare charged by private transit operators as practised in developed countries has brought about hardship on the passengers. This has encouraged the operators to charge abrasive fare (Ndikom, 2008). This has socioeconomic implications on the passengers who are mostly low-income earners. For example, the operators hike fare arbitrarily during traffic hold up, peak period, festive period, fuel scarcity and at night. Sometimes, the number of passengers waiting to board bus at the stop or park determines the extent to which the operator hikes the fare. Thus, they constitute themselves to a cartel and unilaterally hike fare to an astronomical level.

The fare system in operation in the study area does not conform to any conventional methods of setting fare discussed earlier. However, the fare setting shares some similarities with operator's fare setting and special industry fare setting. The main difference is that there is no regulatory agency to determine the minimum and or maximum cap for the fare and monitors the frequency at which the fare is changed to prevent them from abusing this right. The private transit operations in Lagos can best be described as unregulated due to the manner in which they fix and increase fare without any control or justifiable reasons. The result of the study reveals that there is no efficient pricing of transport services in Lagos and other parts of the country. The transport operator enjoys adequate revenue but there is no price efficiency for the passengers. This call for policy action by government to regulate transit fare so that passengers can know the exact amount payable to transit operators, thereby eliminating overcharging and exploitation.

\section{Fare pricing methods}

The private transit operators and their unions adopted zonal fare structure graduated by distance to determine the fare paid by passengers. The fare changes as the bus move from the origin/bus terminal with each successive zone attracting higher fare than the previous along the route of journey. The private transit operators are self centred and profit-conscious when setting fare (Ndikom, 2008). The union executives (NURTW) mostly determine the fare but this does not stop some operators hiking the fare at their whim and caprice especially when they had left the bus terminal. The main challenge with fare pricing is that majority of the operators are illiterate who lack expertise/knowledge to properly calculate the vehicle operating costs such as fuel, repairs and maintenance, tyres, vehicle insurance and licences, union dues, wages etc. to determine the right fare in a professional manner. However, they employ crude means to calculate the vehicle operating costs and add their profit margin to determine the fare paid by passengers. This type of pricing share some similarities with the second best pricing in which all costs are met by setting price equal to the average cost. This pricing method allows 
the operators to generate enough revenue that cover all costs and make some profit. Government does not provide any form of subsidy for the private transit operators. Hence, the passengers bear the total cost of providing the transit services.

\section{Determinants factors of fare charged}

There is no government agency regulating fare setting in the study area as earlier mentioned. The setting and regulating of fare for bus services is the sole responsibility of private transit operators and their unions. Even though fare setting by the operators does not conform to conventional pricing regimes or methods, they have a set of factors that determine or influence their decision on the pricing of transit services. These factors are discussed in this section.

i. Type of vehicle - There is competition among the different types of vehicles being used for public transport due to differences in their occupancy capacity. The vehicles with high occupancy capacity charge less fare than those that could only convey a few passengers due to operating advantages. For example, passengers that commute in taxi pay higher fare than those that commute in minibuses. Similarly, operators of buses charges lower fare compared to the minibuses operators due to its advantage of conveying more passengers.

ii. Vehicle availability - The availability of public transport in right quantity will reduce fare whereas its inadequacy is capable of increasing fare. The shortage of vehicles during the morning and evening peak periods has encouraged the transit operators to hike fare indiscriminately. For example, the private operators hike fare by $100-200 \%$ depending on the route, time of day and number of passengers waiting to board. The peak and off peak fare is also practised in advanced countries but it is regulated by government agency. The intention is to discourage leisure and shopping commuters to make trips during the morning rush hour so as to reduce volume of traffic on the road.

iii. Operating cost - The operating cost for bus service plays an important role in the fare level. The price of vehicles, fuel, engine oil, tyres, battery, union dues, park dues, as well as traffic congestion experienced on the road daily accumulate to determine the fare charge by transit operators. Where the prices of inputs are moderate, the fare will be low. On the contrary, the fare will be very high if the prices of inputs are exorbitant as it is being experienced in most parts of the country today. For instance, the hike in pump price of fuel in May 2016 from $\$ 97$ to $\$ 145$ and devaluation of the currency from $\$ 197$ to $\$ 297$ not only increased transit fare but also led to general increase in prices of goods and services in the country.

iv. Quality of service - The quality of service rendered by public transit operators' play a significant role in determining the fare charged. This has to do with the convenience of journey, seating condition, speed and level of service the passengers enjoyed while travelling in the vehicle. For example, taxi charges higher fare than minibuses due to increased convenience, better seating condition and speed. Many of the buses and mini buses are in deplorable conditions and the services rendered are poor.

v. Road condition - The condition of road plied by the transit operators is a major determinant of transit fare charge. Good road encourages smooth journey, low operating cost and low fare. On the contrary, bad road condition attracts higher fare to cater for the increase in operating costs. For example, the operators that ply motorable roads charge lower fare compared to those that ply routes that are in deplorable conditions in Lagos. 
vi. Government policy - Government agencies are saddled with the responsibility of regulating the activities of the public transit operators, which covers fare and other operational issues. In the study area, government does not have any direct control in determining the fare charged by operators. However, local government sometimes charge the operators some token for making use of public properties like motor park. The fee collected to some extent adds to the fare charged by transit operators.

\section{Perception of passengers to transit fare}

The willing 200 passengers at the bus parks (100 passengers each at Oshodi and Obalende bus parks) were sampled to ascertain their views on fare charge by transit operators. The analysis of the survey was aggregated since the same transit operators provide the service at the parks. The gender of passengers reveals that $59.5 \%$ were male while $40.5 \%$ were female (see Table 1). The majority (80\%) of respondents fall within age bracket of 31-60 years. This is active period in life when people make social and economic trips frequently. The majority of the respondents are literate with 51\% having obtained a tertiary education degree. $79.7 \%$ of them are gainfully employed in white-collar job or private business and at least $86.5 \%$ earn more than $\$ 18,000$ (national minimum wage) as monthly income. Despite this, majority of the respondents are low-income earners as $90 \%$ of them earn less than $\$ 340$ a month at $\$ 297$ to $\$ 1$. This may be responsible for their dependence on public transport to satisfy their travel needs.

The passengers were asked to express their views on the fare charged by transit operators. They indicate that the fare is high with an average of $\$ 639$ per day corresponding to $\$ 12,780$ a month based on 20 working days per month (see Table 2). This result reveal a startling revelation when the amount spent on transport in a month is compared to monthly income of respondents. The transport fare account for $51 \%$ of income of those that earn not more than $\$ 25,000$ per month, $34 \%$ for those that earn between $\$ 25,001-\$ 50,000$ and $20 \%$ for $\$ 50,001$ $\$ 75,000$ income bracket. This calls for policy actions that will address the situation. 
Table I: Socio-demographic attributes of respondents

\begin{tabular}{|c|c|c|}
\hline Factors & Frequency & Percent \\
\hline \multicolumn{3}{|l|}{ Gender } \\
\hline Male & 119 & 59.5 \\
\hline Female & 81 & 40.5 \\
\hline Total & 200 & 100.0 \\
\hline \multicolumn{3}{|l|}{ Age } \\
\hline Less than 30 years & 32 & 16.0 \\
\hline 31 - 40 years & 46 & 23.0 \\
\hline 41 - 50 years & 54 & 27.0 \\
\hline $51-60$ years & 60 & 30.0 \\
\hline Above 60 years & 8 & 4.0 \\
\hline Total & 200 & 100.0 \\
\hline \multicolumn{3}{|l|}{ Education status } \\
\hline No formal education & 11 & 5.5 \\
\hline Primary education & 23 & 11.5 \\
\hline Secondary education & 64 & 32.0 \\
\hline Tertiary education & 102 & 51.0 \\
\hline Total & 200 & 100.0 \\
\hline \multicolumn{3}{|l|}{ Occupation } \\
\hline White collar & 84 & 42.0 \\
\hline Self employed & 75 & 37.5 \\
\hline Student & 25 & 12.5 \\
\hline Retiree & 16 & 8.0 \\
\hline Total & 200 & 100.0 \\
\hline \multicolumn{3}{|l|}{ Monthly income } \\
\hline Below $\$ 25,000$ & 27 & 13.5 \\
\hline$\# 25,001-\$ 50,000$ & 66 & 33.0 \\
\hline$\$ 50,001-\$ 75,000$ & 49 & 24.5 \\
\hline$\# 75,001$ - $¥ 100,000$ & 38 & 19.0 \\
\hline Above $¥ 100,000$ & 20 & 10.0 \\
\hline Total & 200 & 100.0 \\
\hline
\end{tabular}

Furthermore, the result of survey show that about $80 \%$ of passengers indicate that the fare charged by the transit operators is high. This corroborate earlier finding about the high fare paid by the respondents on monthly basis. The high fare can be attributed to non-regulation of transit operations by regulatory agency. This has unleashed untold hardship on the commuters whose income are meagre and can hardly meet their basic needs. Though, majority of the commuters agreed that the fare charged is high the effect on them differs. Half of the passengers indicate that fare has low effect on them. The passengers that experience high impact are mostly those that earn below $\$ 50,000$ as monthly income. Also, the respondents showed their displeasure to the service rendered by the private transit operators. The result reveals that about 78\% were partly satisfied with the services rendered to them. The reasons for the dissatisfaction are due to poor vehicle and seating condition, high transport fare and poor service delivery. 
Table II: Perception of respondents to transport services

\begin{tabular}{|c|c|c|}
\hline \multirow{2}{*}{$\begin{array}{l}\text { Factors } \\
\text { Daily fare }\end{array}$} & Frequency & Percent \\
\hline & & \\
\hline Below $\$ 250$ & 20 & 10.0 \\
\hline \#251-\#500 & 43 & 21.5 \\
\hline$¥ 501-\# 750$ & 65 & 32.5 \\
\hline$\$ 751-\# 1000$ & 48 & 24.0 \\
\hline Above $\$ 1000$ & 24 & 12.0 \\
\hline Total & 200 & 100.0 \\
\hline \multicolumn{3}{|l|}{ Fare level } \\
\hline High & 152 & 79.0 \\
\hline Low & 42 & 21.0 \\
\hline Total & 200 & 100.0 \\
\hline \multicolumn{3}{|l|}{$\begin{array}{l}\text { Effect of fare on } \\
\text { income }\end{array}$} \\
\hline High impact & 96 & 48.0 \\
\hline Low impact & 104 & 52.0 \\
\hline Total & 200 & 100.0 \\
\hline \multicolumn{3}{|l|}{$\begin{array}{l}\text { Satisfaction } \\
\text { service }\end{array}$} \\
\hline Highly satisfied & 45 & 22.5 \\
\hline Fairly satisfied & 122 & 61.0 \\
\hline Not satisfied & 33 & 16.5 \\
\hline Total & 200 & 100.0 \\
\hline
\end{tabular}

\section{CONCLUSION}

The study examine the regulation and pricing of public transport operations in Lagos, Nigeria. This study focuses on the agency regulating transit fare, fare pricing methods as well as perception of passengers to fare. The findings reveal that there is no government agency regulating transit fare in Lagos although the power has been vested on Lagos Metropolitan Area Transport Authority. The fixing of fare is the exclusive right of the private transit operators without any form of control or monitoring. The result further shows that private transit operators charge high fare, which generate enough revenue to cover all costs and make profit. They use unprofessional method similar to average cost to calculate the fare charged. The zonal fare structure is employed by the transit operators to determine the fare paid by passengers. The non-availability of agency regulating transit pricing in the country encouraged charging of abrasive fare especially during traffic hold up, peak periods, fuel scarcity and festive periods without any justifiable reasons.

The important factors determining the amount of fare charged includes types of vehicle, operating costs, service quality, vehicle availability and road conditions. The passengers are of the opinion that the transport fare is high accounting for substantial part of their monthly income. The high fare does not correspond with the services rendered by the private transit operators whose vehicles are in poor conditions.

The study concludes that transit operations and pricing in the country is not properly regulated. This has made fare to be high which has socio-economic implications on the poor riders. The study recommends that government agency saddled with the responsibility of regulating fare should be mandated to perform their duties. This will stop the exploitative tendencies of the private transit operators. The agency is expected to formulate policy that will 
achieve uniform and realistic fare setting and transit pricing regimes for intra and inter city travels in the study area. The decisions should be communicated to the leadership of transport unions to operationalize while officials of the agency must ensure compliance through adequate control and monitoring. Finally, the study recommends that government should participate more actively in the provision of public transport services so as to create greater choices and reduce transport fare through competition.

\section{References}

Adeniji (1987) Para-transit models in Nigeria: problems and prospects. Cities 4(4), 339-347.

Akin, D. (2006) A mode for estimating increased ridership due to integration of two urban transit models: Case study of Istanbul's metro and bus/minibus transit systems. Proceedings of the 85th Transportation Research Board Meeting, January 22-26 2006, Washington D.C.

Anas, A. and Lindsey, R. (2011) Reducing urban road transportation externalities: Road pricing in theory and in practice. Review of Environmental Economics and Policy 5(1), 66-88.

Baker, S., and White, P. (2010) Impacts of free concessionary travel: case study of an English rural region. Transport Policy 17(1), 20-26.

Braeutigam, R.R. (1989) Optimal policies for natural monopolies. In Handbook of Industrial Organization, edited by Schmalensee, R., and R.D. Willig, 1289-1346. North-Holland: Elsevier.

Button, K. J. (1986) Developments in the regulation of the United Kingdom bus industry. Transportation Journal 25(3), 43-59.

Deb, K. and Filippini, M. (2011) Estimating welfare changes from efficient pricing in public transit in India. Transport Policy 18(1), 23-31.

Fadare S.O. and Wojuade C.A. (2007) Study of traffic delay situation in Ibadan, Nigeria. Ife Planning Journal, 3(1), $1-15$.

Garcia, S. and Reynaud, A. (2004) Estimating the benefits of efficient water pricing in France. Resources and Energy Economics 26, 1-25.

Gkritza, K., Karlaftis, M. G., and Mannering, F. L. (2011) Estimating multimodal transit ridership with varying fare structure. Transportation Research Part A (45), 148-160.

Gomez-Ibanez, J.A. (1999) Pricing. In Essays in Transportation Economics and Policy: A Handbook in Honor of John R. Meyer, edited by Gomez-Ibanez, J.A., Winston, C.A., and W.B. Tye, 99-136. Washington, DC: The Brookings Institution Press.

Ikporukpo, C. O. (1998) Urban mass transit as a public sector concern: The Nigerian Experience. The Nigerian Journal of Economic and Social Studies 40(2), 229-239.

National Population Commission (2007) The National and State Provisional Population Totals 2006. Lagos, The Federal Government Printer.

Ndikom O. B. C. (2008) Fare Systems and Strategies in Element of Transport Management. Lagos, Bunmico Publishers.

Nuwursoo, C., Golub, A., and Deakin, E. (2009) Analyzing equity impacts of transit fare changes: Case study of Alameda-Contra Costa Transit, Califonia. Evaluation and Program Planning, 32(4), 360-368.

Ogunbodede, E. F. (2008) Urban Road Transportation in Nigeria from 1960-2006: Problems, Prospects and Challenges. Ethiopian Journal of Environmental Studies and Management, 1(1), 23-31.

Ojekunle, J. A. (2014) Analysis of fare structure and determinant of bus operations in Nigeian cities. International journal of Developing Societies, 3(2), 13-21.

Okoko, E. (2006) Transportation Planning and Management in Urban Transportation Planning and Modelling. Akure, Millenium Publishers.

Preston, J. (2014) A fare deal? Regulation and financing of bus services in Wales. Public Policy Institute for Wales, PPIW Report No. 9, UK.

Rothengatter, W. (2003) How good is first best? Marginal cost and other pricing principles for user charging in transport. Transport Policy 10(2), 121-130. 
Savage, I., and Schupp, A. (1997) Evaluating transit subsidies in Chicago. Journal of Public Transportation, 1, 93117.

White, P. (1981) Recent developments in the pricing of local public transportation services. Transport Reviews 1(2), 127-150.

World Bank (1990) Nigeria urban transport in crisis. Report No. 8974-UNI, Washington, DC.

World Bank (2011) Fare collection systems - Lagos, Nigeria.

<https://www.ssatp.org/sites/ssatp/files/publications/Toolkits/Fares\%20Toolkit\%20content/casestudies/lagos-nigeria.html> Accessed August 7, 2017. 